\title{
A millstone around the neck? Stereotypes about wives and myths about divorce
}

\author{
SHARON THOMPSON \\ School of Law and Politics, Cardiff University ${ }^{1}$
}

\begin{abstract}
This article examines the effect of and connection between stereotypes about wives and myths about financial provision on divorce. It is based on an assessment of press reports on Mills $\mathrm{v}$ Mills which have fuelled calls for reform of the law of financial provision on divorce, most notably the Divorce (Financial Provision) Bill 2017-2019. It argues that gendered stereotypes about wives (such as 'alimony drone', 'gold-digger' and 'meal ticket for life') inbibit shifts towards substantive equality for women. These gendered stereotypes have not only framed the debate, creating a non-existent problem for reform proposals to solve, but have also affected the way in which individuals form family law agreements, which is important given the current policy emphasis on private ordering. The article concludes by proposing that reflexive engagement with stereotypes about wives should be an important part of judicial reasoning.
\end{abstract}

Keywords: financial provision on divorce; Mills v Mills; gold-digger; alimony drone; meal ticket for life; judicial notice; nuptial agreements; financial settlements

\section{Introduction}

Tn 1983, Juanita Frances (founder and then President of the Married Women's Association $)^{2}$ wrote: 'It is said the media's campaign is a backlash against the modicum of equality women have so far achieved. ${ }^{3}$ She was referring to the Justice in Divorce campaign in the 1980 s that contributed to the introduction of the 'clean-break' principle 4 which facilitated the ending of financial ties between divorcing spouses (and in particular the payment of spousal support). ${ }^{5}$ This Justice in Divorce campaign was not about the

1 Earlier versions of this paper were presented at the Universities of Durham, Warwick, Bristol and NUI Galway between 2017-2018. I would like to thank the attendees at these talks for their valuable comments, and to Dr Andy Hayward, Dr Illan Wall, Dr Katie Cruz and Dr John Danaher for inviting me to present this research on those occasions. I am also indebted to Professor Russell Sandberg for his detailed feedback on this article, and I am very grateful to the anonymous reviewers for their insightful, helpful and comprehensive comments.

2 The Married Women's Association was formed in 1938 and disbanded in 1988. It campaigned for marriage to be recognised as an equal financial partnership in law: Sharon Thompson, 'Married Women's Property Act 1964' in Erika Rackley and Rosemary Auchmuty (eds), Women's Legal Landmarks (Hart 2018) ch 36.

3 Letter from Juanita Frances (25 January 1983), London School of Economics, The Women's Library, Records of the Married Women's Association, 5MWA/5.

4 Matrimonial and Family Proceedings Act 1984, amending the Matrimonial Causes Act 1973.

5 Gillian Douglas, Obligation and Commitment in Family Law (Hart 2018) 120. 
severe impact separation could have on wives; it was about the alleged injustice of divorce for men. ${ }^{6}$ The "lively ${ }^{7}$ campaign received extensive media coverage, and Frances was right to be concerned about the consequences of this when she said:

The controversy has vilified women and branded them with a 'meal ticket for life' syndrome. Accusations in the press have made them out as 'alimony drones', and the public has responded with concern that there could not be smoke without fire. Both men and women have jumped into the fray, showing bias and prejudice against the true state of the economically depressed position of women and children in divorce. ${ }^{8}$

Frances incisively captures the harm caused by stereotypes about women on divorce. The media's portrayal of wives as unfairly leeching from their ex-husbands in the 1980s9 influenced public opinion and undermined the spirit of the Matrimonial Property and Proceedings Act 1970 which recognised the property entitlements of spouses as a result of their unpaid work in the home. Gillian Douglas notes that the many complaints about wives receiving 'meal tickets for life' came from 'disgruntled husbands and their second wives' and that the Law Commission focused on their hardship. ${ }^{10}$ However, contemporary research findings suggested that the amount of maintenance transferred to former wives was significantly lower than media reports suggested. ${ }^{11}$

It is disappointing, yet predictable, given the formal equality and neoliberal influences discussed later in this article, that more than 35 years later, media coverage of Baroness Deech's Divorce (Financial Provision) Bill 2017-2019 make Frances' words resonate loudly. Once again, there is a media backlash against the move towards equality as articulated in 2000 by the House of Lords in White $v$ White. ${ }^{12}$ The power of this backlash is perpetuated by Baroness Deech who has argued her reform is urgent because:

The wife who is least likely ever to have put her hand in cold water during the marriage is the one most likely to walk off with millions, regardless of her contributions or conduct. Hence we find that London is the divorce capital of the world for the wealthy, and the phrases 'gold digger' or 'alimony drone' have been coined. ${ }^{13}$

Drawing on my earlier research on the historical context of the gold-digger, ${ }^{14}$ this article will take a closer look at this media backlash. For the first time, this article explores the use of stereotypes about wives in press reports concerning a judicial decision and how these stereotypes have fuelled calls for reform. In part one, the most prevalent stereotypes

6 Stephen Cretney, Family Law in the Twentieth Century: A History (Oxford University Press 2003) 139.

7 Douglas (n 5) 121.

8 Frances (n 3).

9 See Andrew Gilbert, British Conservatism and the Legal Regulation of Intimate Relationships (Hart 2018) ch 3.

10 Douglas (n 5) 121. Law Commission, The Financial Consequences of Divorce: The Basic Policy, A Discussion Paper (Law Com No 103, 1980). For a contemporary summary of the impact of the clean-break principle's introduction in 1984, see Pamela Symes, 'Indissolubility and the Clean Break' (1985) 48(1) Modern Law Review 44.

11 As Miles and Hitchings have pointed out, while advocates of reform complained of former wives unfairly and parasitically exhausting their ex-husband's resources, Maclean and Eekelaar's research showed that 'the amounts of maintenance transferred were very low, and constituted a much lower percentage of payors' household income than of recipients': Joanna Miles and Emma Hitchings, 'Financial Remedy Outcomes on Divorce in England and Wales: Not a "meal ticket for life" (2018) 31(2) Australian Journal of Family Law 4380, citing John Eekelaar and Mavis Maclean, Maintenance after Divorce (Clarendon Press 1986).

12 [2000] UKHL 54.

13 HL Deb 27 June 2014, vol 754, col 1491.

14 Sharon Thompson, 'In Defence of the Gold-digger' (2016) 6(6) Oñati Socio-Legal Series 1225-1248. 
about wives in the media are introduced and contextualised. Following this, part two takes a closer look at how such stereotypes are utilised. It will do this by studying six national press reports published online over the course of one week ${ }^{15}$ following the Court of Appeal decision in the financial remedies case Mills $v$ Mills. ${ }^{16}$ These press reports are evaluated to ascertain how stereotypes about wives are communicated to readers, and so the focus is on coverage of Mills rather than an analysis of the case itself. Though Mills has now been decided in the Supreme Court, ${ }^{17}$ the Court of Appeal coverage is studied instead to assess initial reporting of the facts of the case. ${ }^{18}$

Press coverage of financial provision on divorce arguably plays an important role in shaping public perceptions, ${ }^{19}$ and so, in part three, the effect of stereotypes prevalent in the press reports from part two is further explored. It will be argued that the unsubstantiated fear of terms like 'alimony drone', 'gold-digger' and 'meal ticket for life'20 have led to continued calls for sweeping reform (including binding prenuptial agreements) ${ }^{21}$ and claims that England and Wales are undesirable places for wealthy men to get divorced. ${ }^{22}$

In addition to highlighting the ramifications of stereotypes about women and the subsequent myths promulgated on divorce, along with their practical and damaging impacts, in part four this article also confronts the question of what can be done to counter them. The aim of this analysis is not only to expose the empirical evidence undermining claims of gold-digging in financial provision cases. Rather, it is to follow the work of Rosemary Hunter, Angela Melville ${ }^{23}$ and others, ${ }^{24}$ who have sought to challenge family law 'post-truths'. As a result, this article contends that negative stereotypes about women are dominant because those who talk about tropes such as gold-digging believe incorrectly that it is a widespread social problem. These perceptions are increasingly effective in family law, as the withdrawal of legal aid ${ }^{25}$ means couples increasingly must reach their own financial settlements on divorce. ${ }^{26}$ When these settlements depend on

15 6-12 February 2017.

16 [2017] EWCA Civ 129.

17 Mills v Mills [2018] UKSC 38.

18 Much of the reporting on the appeal to the Supreme Court and the Supreme Court decision repeats the information published in the initial reporting of the case.

19 This is also argued in the context of the criminalisation of paid homecare workers in Lydia Hayes, 'Sex, Class and CCTV: The Covert Surveillance of Paid Homecare Workers' in Lisa Adkins and Maryanne Dever (eds), The Post-Fordist Sexual Contract: Working and Living in Contingency (Palgrave 2015) 171, 183.

20 In particular, see Miles and Hitchings (n 11), which outlines findings from a range of data sets showing that the meal-ticket-for-life concern is unfounded.

21 Divorce (Financial Provision) Bill 2017-2019; Frances Gibb, 'Family Matters: Urgent Call for New Divorce Laws as Judges Demand Overhaul of “Corrosive” System' The Times (London, 19 November 2017) <https://www.thetimes.co.uk/edition/news/urgent-call-for-new-divorce-laws-as-judges-demand-overhaulof-corrosive-system-8k0ncg7gt $>$.

22 See, for instance, the second reading debate of the Divorce (Financial Provision) Bill 2017-2019, where Baroness Deech reiterated the now commonly used phrase that London is the 'divorce capital of the world': HL Deb 11 May 2018, vol 791, col 376.

23 Rosemary Hunter and Angela Melville, “As Everybody Knows”: Countering Myths of Gender Bias in Family Law’ (2001) 10(1) Griffith Law Review 124.

24 Maebh Harding and Annika Newnham, 'Initial Research Findings: The Typical Levels of Parental Involvement where Post-separation Parenting is Resolved by Court Order' (2014) 44(5) Family Law 672; Julie Doughty, Lucy Reed and Paul Magrath, Transparency in the Family Courts: Publicity and Privacy in Practice (Bloomsbury 2018); Miles and Hitchings (n 11).

25 Pursuant to the Legal Aid, Sentencing and Punishment of Offenders Act 2012.

26 See Emma Hitchings, 'Official, Operative and Outsider Justice: The Ties that (May not) Bind in Family Financial Disputes’ (2017) 29(4) Child and Family Law Quarterly 359. 
parties' respective negotiating strengths, the non-moneyed spouse's bargaining position is weakened by the perception that she will be an undeserving gold-digger or parasitic alimony drone if she asks for more money than her spouse is willing to part with. If the influence of stereotypes about wives is therefore not fully recognised, our understanding of the context in which settlements are reached on divorce is incomplete. It is imperative that the effect of gendered stereotypes on these settlements is recognised because, as contract theorists like Eric Posner assert, the reality in which parties make agreements is complex and 'powerful social norms may play a greater role in regulating contracts than the law does' ${ }^{27}$ Crucially, inaccurate stereotypes are harmful as they mis-frame and diminish the real issues of economic disadvantage on divorce experienced by those with caring responsibilities. Reflexivity is therefore essential in judicial reasoning, to acknowledge this broader context and to tackle tropes head on in judgment-making.

\section{Stereotypes about wives}

'Alimony drone' and 'gold-digger' are gendered phrases in that they are applied almost exclusively to women. Even the definitions of 'gold-digger' and 'alimony drone' in the Oxford English Dictionary (OED) refer explicitly to women and not men. ${ }^{28}$ The OED defines 'alimony drone' as: 'A woman who lives on alimony payments and makes no attempt to support herself.' ${ }^{29}$ Similarly, 'gold-digger' is defined in the OED as: 'A woman who forms relationships with men purely to obtain money or gifts from them.' ${ }^{30}$ These definitions tell us that, first, women to whom these labels are attached are either deliberately economically dependent or are concerned solely with material gain and, secondly, that men are not alimony drones or gold-diggers. As a result, when these terms are employed in the media, they are used to vilify women, not men. Ultimately, and as the following analysis illustrates, these terms lead to women's intentions being questioned when entering relationships like marriage and when negotiating financial settlements on divorce. Even worse, the phrases 'gold-digger' and 'alimony drone' can be used arbitrarily regardless of women's intentions when marrying or divorcing. This is evidenced in Terry Arendell's research on the enactment of gender in interviews with divorced men. She found that "most ... interviewees believed, and insisted repeatedly, that women unjustly "soak" or "bleed" men dry economically on divorce'. 31

This is also inextricably linked to the common perception that women are routinely granted a 'meal ticket for life' by the court on divorce. The 'meal ticket' phrase is generally associated with 'joint lives' orders, whereby spousal maintenance lasts indefinitely until

27 Eric Posner, 'A Theory of Contract under Conditions of Radical Judicial Error' (2000) 94 Northwestern University Law Review 749.

28 The term 'fortune hunter' has historically been applied to men, but the dictionary definition is gender neutral: see < https://en.oxforddictionaries.com/definition/fortune_hunter>. This is interesting given that nineteenth-century literature frequently casts the fortune hunter as a man seeking to marry a woman of wealthy status (see, for example, Mr Wickham in Jane Austen, Pride and Prejudice (T Egerton 1813)) when 'golddiggers' in literature are almost (if not) always women (see, for example, Holly Golightly in Truman Capote, Breakfast at Tiffany's (The Folio Society 2013), a character often labelled as being a gold-digger). While the term 'gold-digger' continues to be part of our vernacular, 'fortune hunter' is not.

29 OED < https://en.oxforddictionaries.com/definition/alimony_drone>.

30 OED < https://en.oxforddictionaries.com/definition/gold-digger $>$.

31 Terry Arendell, 'Reflections on the Researcher-Researched Relationship: A Woman Interviewing Men' (1997) 20(3) Qualitative Sociology 341. 
the court orders otherwise, the recipient re-partners ${ }^{32}$ or one of the parties dies. ${ }^{33}$ Quantitative and qualitative research ${ }^{34}$ by Joanna Miles and Emma Hitchings shows that such orders are rare and that, more broadly, spousal support is generally awarded to mothers caring for minor dependent children. Overall, they found that women continue to be economically disadvantaged following divorce. ${ }^{35}$ Their research shows that, for instance, The Times' reporting on the 'propensity of the family courts to make spousal maintenance awards for life'36 is wrong. Instead, the opposite is true - all their data indicated a 'clean break culture'. From a data set of 399 court files, joint lives orders were made in just 5.5 per cent of cases. Similarly, in Hilary Woodward's survey of 369 court cases, only 2 per cent were joint lives orders for more than a nominal amount. ${ }^{37}$ This indicates that whilst gold-digger, alimony drone and meal-ticket-for-life tropes are made credible by media reporting, such reports do not reflect the reality for women on divorce.

Believing in these stereotypes has consequences. As Sandra Fredman put it:

Stereotypical images of women have throughout the ages been used to justify detrimental treatment. Because women are classified as different in the relevant respects, it appears justifiable to subject them to detrimental treatment. ${ }^{38}$

Ingrained by long-standing biases, the stereotypes of alimony drones, gold-diggers and meal tickets for life have a personal cost for women. They are contributing to a shift in how women's economic entitlement is perceived on divorce and assist in justifying detrimental treatment of women. Perhaps most significantly, such tropes can affect the actual resolution of financial disputes on divorce. Hunter et al have shown that disputes are often affected by the emotional and moral norms of the parties. ${ }^{39}$ Their empirical findings drawn from interviews with parties with experience of dispute resolution 40 indicated that for women these included 'feelings of guilt, pragmatism, sacrifice or selfpreservation, concerns about compensation or a desire for reasonableness, which were rarely put forward by men'. In contrast, Hunter et al found that men expressed the norm of formal equality twice as often as women. This context of formal equality masks dependency and is tied to the trope of the independent woman, celebrates independence, and encourages women to react in a visceral way to the accusation of the gold-digger, by either seeking to prove they don't need their partner's money, or by vilifying women who do. Yet, as Joan Tronto argues, assuming the existence of autonomous actors (as most democratic political theories do) does not explain 'how individuals can balance autonomy

32 The maintenance will commonly terminate following long-term cohabitation and will always terminate upon remarriage.

33 See s 28(1) of the Matrimonial Causes Act 1973.

34 Drawn from interviews with practitioners in England in 2012-2013, two focus group discussions conducted in 2016 with 14 first instance judges and a court file survey of $c 400$ cases collected in 2012 from cases concluded between 2010-2012.

35 Miles and Hitchings (n 11). This finding is consistent with empirical research since the 1980s, discussed later in this article.

36 Michael Gouriet, 'Meal Ticket Appeal: Court Endorses a Clean Break' The Times (London, 26 April 2018) <https://www.thetimes.co.uk/article/meal-ticket-appeal-court-endorses-a-clean-break-nvm3gl20p>.

37 Hilary Woodward, "Everyday" Financial Remedy Orders: Do They Achieve Fair Pension Provision on Divorce?’ (2015) 27(2) Child and Family Law Quarterly 151, 164.

38 Sandra Fredman, Women and the Law (Clarendon Press 1998) 301.

39 Rosemary Hunter, Anne Barlow, Janet Smithson and Jan Ewing, 'Law, Discretion, Gender and Justice in Outof-Court Financial Settlements' (2018) 31(2) Australian Journal of Family Law 189-203. See also Emma Hitchings, Joanna Miles and Hilary Woodward, Assembling the Jigsaw Puzzle on Divorce (University of Bristol 2013) for findings on how non-legal factors influence the process of dispute resolution.

40 This was part of a broader study by Hunter et al investigating out-of-court family dispute resolution processes and outcomes in England and Wales in both children's and financial matters between 1996 and 2014. 
and dependency in their lives'. ${ }^{41}$ Neither does it acknowledge the network of relationships and responsibilities that inherently impact decision-making surrounding the negotiation of financial settlements on divorce. ${ }^{42}$ Therefore, formal equality and the assumption that everyone is equally autonomous 'reiterates well-worn patterns of discriminatory attitudes'. ${ }^{43}$ As Emma Hitchings has aptly put it, formal equality's appearance of neutrality 'highlighted through the use of terms such as fairness, equality, settlement and autonomy' can mean that women are 'particularly vulnerable during financial settlement negotiations' ${ }^{44}$

This is exacerbated by the dichotomy of 'gold-digger' and 'independent woman' often employed in media reports on divorce which contributes to the voices of the broad spectrum of women in between being silenced and lost. This includes an individual who becomes economically dependent on her partner because marriage does create interdependence, especially when there are children. She might make decisions for the welfare of the family that mean sacrificing her earning power. ${ }^{45}$ And whilst she is not a gold-digger nor entirely self-sufficient, she is likely to be affected adversely by these powerful tropes.

As a result, this article investigates how stereotypes about wives have helped create a backlash against efforts to implement substantive equality and recognise care. This is significant because it leads to false perceptions about the law, which in turn seeps into public consciousness and could affect how parties negotiate financial settlements and future reform. To this end, I will first examine press coverage of wives and financial provision on divorce through a study of Mills $v$ Mills. ${ }^{46}$

\section{Mills v Mills in the news}

My earlier work has shown how the phrase 'gold-digger' has been used as a weapon against women, which creates an image of wives as predatory and obscures the causes of economic dependency in the relationship. ${ }^{47}$ To understand the wider cultural context of such images, and to help reveal how stereotypes enter the public domain, this section examines six national press reports ${ }^{48}$ concerning the 2017 Court of Appeal financial provision case Mills $v$ Mills. ${ }^{49}$ The media reporting of wives in financial provision cases is an important part of this story. These reports illuminate media misunderstandings of the law of financial provision on divorce that are in turn likely to encourage public misunderstandings, showing how stereotypes about wives are linked to myths about the law. An awareness of this is important. ${ }^{50}$ When decisions are made over financial settlements, nuptial agreements and the terms of such agreements, negotiations and the

41 Joan C Tronto, Caring Democracy: Markets, Equality and Justice (New York University Press 2013) 31.

42 Jonathan Herring, Relational Autonomy and Family Law (Springer 2014) 68. See also Sharon Thompson, Prenuptial Agreements and the Presumption of Free Choice (Hart 2015) ch 6.

43 Tronto (n 41) 31.

44 Hitchings (n 26) 361.

45 See Anna Heenan, 'Causal and Temporal Connections in Financial Remedy Cases: The Meaning of Marriage' (2018) 30(1) Child and Family Law Quarterly 75.

46 Mills (n 16).

47 Thompson (n 14).

48 This approach has been adopted in relation to press reporting on paid homecare workers: Hayes (n 19$) 171$. For more media reports on Mills (n 16) not included in this article, see: 'Mrs Millstone . . . ?' The Transparency Project (12 February 2017) <www.transparencyproject.org.uk/mrs-millstone>.

49 Mills (n 16).

50 Doughty et al (n 24). 
exercise of power between the parties are affected by the gulf between public perceptions of the law ${ }^{51}$ and how the law operates in practice. ${ }^{52}$

To emphasise the impact of media reporting on our understandings of events related to financial relief proceedings, I deliberately do not outline the facts of Mills $v$ Mills before presenting media reports on this case so that these reports can be taken at face value. The sample of reports was put together by researching the 10 most-read news titles in the UK according to Ofcom. ${ }^{53}$ From these titles, four sources were selected which covered Mills more than other titles, ${ }^{54}$ and online articles published by these news titles were selected over a week-long period following the Court of Appeal decision (6-12 February 2017). The sample focuses on Court of Appeal coverage, as reports on the Supreme Court decision repeat much of the initial reports.

\section{Headline 1: 'Divorced men doomed to life as a cash machine.'55}

This article presents the facts of this case as being simply that Mr Mills divorced his wife 15 years ago but has had to increase his payments to her because she had spent her divorce settlement. The phrase 'gold-diggers' is used in the article, and the author is highly critical of the law:

It's often claimed that ex-wives can see their former husbands as cash machines, compounding this by stripping them of the human right of fatherhood. This not only flies in the face of equality but can also cause men to question their desire to live. In the past seven years suicides among men aged $45-49$ have risen by $40 \%$.

This report makes it clear that the outcome for the husband in Mills $v$ Mills was in the author's view unfair and then uses this case to make a broader statement about the current law. The author calls for reform of the law of financial provision on divorce, connecting its injustice to male suicides. The headline and article misrepresent the joint lives order at issue in Mills, by explaining it as being 'an allowance she will enjoy for the rest of her life'. If Ms Mills re-partners or if her circumstances change, the order can be reviewed.

Headline 2: 'Court orders man to increase payments to wife who lost bulk of divorce settlement with poor financial decisions.' 56

The facts of Mills $v$ Mills are ostensibly outlined in this report, whereby Ms Mills 'leaves the marriage with all, or almost all the liquid capital', subsequently loses it, and successfully argues that her periodical payments should be increased. In this article there is detail on Mr Mills' calls for reform of the law, seeking 'changes to the law to limit

51 For instance, there appears to be a common assumption that all assets are automatically split 50/50 on divorce under English law, as indicated on several family law practitioner websites (including: <https://harrogatefamilylaw.co.uk/is-everything-always-split-5050-in-divorce/>; www.portner.co.uk/news/divorce-myth-busting-the-couple-s-assets-are-always-divided-50-50).

52 The financial outcome on divorce is rarely 50/50 and instead depends on exercise of judicial discretion under s 23 of the Matrimonial Causes Act 1973 with a list of factors for the judge to consider under s 25 of the Act. For more detail on this, see Thompson (n 14) 1237.

53 Ofcom, News Consumption in the UK: 2018, 25 July 2018 <www.ofcom.org.uk/research-and-data/tv-radio-andon-demand/news-media/news-consumption>. As reports were taken from online sources, the Daily Mail and Mail on Sunday were treated as being the same source because they were published on the same website.

54 For instance, by 1 January 2019, Mills had been reported 14 times in The Times, 9 times in the Daily Mail, 6 times in The Telegraph and 4 times in the Evening Standard. There were no online news reports in widely read news titles like The Guardian.

55 Martin Daubney, 'Divorced Men Doomed to Life as a Cash Machine' The Times (London, 12 February 2017) $<$ www.thetimes.co.uk/article/divorced-men-doomed-to-life-as-a-cash-machine-lw526hj3n>.

56 'Court Orders Man to Increase Payments to Wife who Lost Bulk of Divorce Settlement with Poor Financial Decisions' The Telegraph (London, 6 February 2017) <www.telegraph.co.uk/news/2017/02/06/court-ordersman-increase-payments-wife-lost-bulk-divorce-settlement/>. 
spouses to five years maximum maintenance'. Although the phrases 'alimony drone' and 'gold-digger' are not used in the article, there are several references to the wife as being financially dependent on Mr Mills without any effort to be self-sufficient. The sense of injustice for Mr Mills is clear, with his QC quoted as saying: 'It is wrong in principle and in law that the wife should continue to depend, and indeed seek to increase, her dependence on the husband.'

Headline 3: 'Business man's fury as judge orders bim to support his ex-wife for life after she blew $£ 230 k$ payout on homes. 57

This article is based on an interview with Mr Mills, which therefore does not present Ms Mills' side of the story. Although other reports implied that Ms Mills had successfully applied to the court for more money, it is revealed in this report that the case was in fact brought by Mr Mills. He sought to have her periodical payments (spousal maintenance) reduced, arguing their adult son is now independent and saying he regretted the original deal made at the time of their separation. Mr Mills' view of the Court of Appeal decision is that it is 'grossly unfair', and he calls for reform of the law:

I don't think it's right that after divorce you should be tied together for ever. I don't think you can move on mentally or physically with that tie in place. The law is wrong in that regard ... I feel like I am paying for her mismanagement of finances ... I'm angry and frustrated the system allows this to happen. I don't really want this to be about me and her, I think there's a wider issue about the law. I've no need to put her down, I'd rather the effort was concentrated on making the law work for people.

Headline 4: "I'm paying for HER mistakes": Husband who was ordered to support his ex-wife for life 15 years AFTER they divorced calls for a time limit on maintenance after she blew ber £230,000 payout on bad investment. 58

This report reinforces the sentiments expressed by Mr Mills in the Evening Standard article. Even the language used in the headline of this article is provocative - 'I'm paying for HER mistakes' clearly elicits sympathy for the husband, anger at the wife and a sense of injustice about the law. We are again told that Mr Mills is 'furious' at the 'grossly unfair' decision reached by the court and the entire article focuses on Ms Mills 'failures' and 'poor financial decisions'.

At this point, taking these reports at face value would lead one to believe that the law does not encourage men and women to be financially independent after divorce. The law is presented as making lifetime awards that unfairly prejudice men and enable women to be alimony drones. And if the Court of Appeal in Mills v Mills is increasing maintenance as a result of the wife's own poor judgement after relationship breakdown, it could be argued that the law is encouraging gold-diggers, and that there does need to be reform as Mr Mills claims. These assumptions are understandable, but further investigation into this case reveals that these press reports have missed key details about the case.

57 David Churchill and Jonathan Prynn, 'Business Man's Fury as Judge Orders Him to Support his Ex-wife for Life after She Blew f230k Payout on Homes' Evening Standard (London, 8 February 2017) <www.standard.co.uk/news/london/businessman-s-fury-as-judge-orders-him-to-support-his-exwife-for-lifeafter-she-blew-230k-payout-on-a3461391.html>.

58 Alex Matthews and Steph Cockroft, “'I'm Paying for HER Mistakes”: Husband who was Ordered to Support his Ex-wife for Life 15 Years AFTER They Divorced Calls for a Time Limit on Maintenance after She Blew her $f_{230,000}$ Payout on Bad Investment' Daily Mail (London, 8 February 2017) <www.dailymail.co.uk/news/article-4204214/Court-order-makes-man-pay-ex-wife-s-mistakes.html>. 


\section{Headline 5: 'Trolls target woman after divorce payout.'59}

This report is one of the few examples where the reader gleans Ms Mills' perspective on the case. She clarifies a few facts that were not made clear in other reports:

It should be noted that since the divorce 15 years ago, I have never returned to the court to increase my maintenance, despite my financial difficulty and bad health and low earnings ... This was Mr Mills's application to the court to reduce or eliminate the maintenance despite the fact our son is still in full-time education and still living with me at home.

Ms Mills also comments on the other press reports on her financial provision case and their effect:

There have been a number of articles published recently in respect of this appeal which give a very one-sided version of the facts in this case ... [t] he tone and content of the reporting has caused me considerable distress, with internet hate mail.

Headline 6: "I'm NOT a gold digger": The ex-wife vilified as a cold, cunning chancer after winning a buge rise in maintenance payments 15 YEARS after her divorce blasts back and says it's all her ex's fault.' 60

This headline is representative of many of those studied, in that it adds to the news rhetoric of stereotypes about wives. As Faith Gordon notes, paying attention to headlines like this is important because it summarises the most 'poignant' pieces of information in a way that attracts the reader's attention and encourages the reader to process the text in a particular way. ${ }^{61}$ This headline is a notable example of this. Though Ms Mills' perspective is reported here, the wording of the headline continues to reinforce the derogatory image created throughout other media reports: Ms Mills as 'a cold, cunning chancer' who 'blasts back' at her ex-husband. This does not invite the reader to be sympathetic about Ms Mills.

In the main text of the report, Ms Mills reveals that the coverage of her case in the press has caused her to be labelled as a gold-digger:

I feel like I have been through a character assassination, both at the hands of my ex-husband and the public. They've said I'm a gold digger. It's not true. I'm nothing of the sort. The past two years of fighting my ex-husband have been incredibly stressful and have taken their toll on me physically and emotionally.

Although The Telegraph reported ${ }^{62}$ that Ms Mills had received all the liquid capital on separation, in this article the reader learns that she did not perceive the original settlement as fair, and she ostensibly did not leave the marriage on an equal footing with her husband:

At the time of our divorce my husband claimed he couldn't afford to buy a house for himself and was renting a room. He suggested I should use $f^{200,000}$ to buy a small, terraced home for me and my son. Yet immediately after everything was

59 Frances Gibb and Jonathan Ames, 'Trolls Target Woman after Divorce Payout' The Times (London, 10 February 2017) <www.thetimes.co.uk/edition/news/trolls-target-woman-after-divorce-payout-ddvqv7qrn>.

60 Olga Craig, "I'm NOT a gold digger": The Ex-wife Vilified as a Cold, Cunning Chancer after Winning a Huge Rise in Maintenance Payments 15 YEARS after her Divorce Blasts Back and Says It's All Her Ex's Fault' Mail on Sunday (London, 11 February 2017) <www.dailymail.co.uk/femail/article-4215578/Maria-hitswinning-increase-maintenance.html>.

61 Faith Gordon, Children, Young People and the Press in a Transitioning Society: Representations, Reactions and Criminalisation (Palgrave 2018) ch 4.

62 See n 56. 
settled he bought a $f 350,000$ house for himself, his girlfriend and her daughter and paid for that daughter's upbringing from the age of eight until she was 23 .

Taken together with the previous report in The Times, 63 the reader learns that, although the Mills' son is an adult, he is not independent in the way Mr Mills stated in the Evening Standard. ${ }^{64}$ Furthermore, although Ms Mills fell into financial difficulty as the press reported, she was not the party who applied to court. It was Mr Mills who brought the case to court because he wanted to terminate (or reduce) the amount of money he was paying Ms Mills, which was $£, 1100$ a month. In answer, Ms Mills asked the court to consider increasing her periodical payments as she was unable to meet her basic needs and ended up winning the appeal, having had to borrow money from friends and family to be able to respond to Mr Mills' application to court. Therefore, Ms Mills does not appear to fit within the dictionary definition of 'gold-digger'. Yet this is what she has been vilified as through press coverage like headlines 1 to 4 , where each report's exposition of limited facts provides a skewed picture of events. ${ }^{65}$

\section{A MILLSTONE AROUND THE NECK?}

Uniting virtually all of the press reports on Mills is the argument that this case highlighted a legal injustice, in that gold-digging or alimony-droning ex-wives are routinely awarded meal tickets for life. The solitary case of Mills $v$ Mills is cited as authority for this, even though the work of Miles and Hitchings has shown this assertion to be unrepresentative. ${ }^{66}$ Consequently, accusations in the press like those surrounding the Mills case suggest there must be 'no smoke without fire' 67 and that the prevalence of 'meal ticket' orders on divorce is of real concern. And so with striking parallels to the Justice in Divorce campaign of the 1980s, The Times subsequently launched its own Family Matters campaign in late 2017 calling for 'urgent' and 'sweeping' reform which would include an 'end to the socalled meal ticket for life maintenance awards'. 68 'The victim of the law' under the Justice in Divorce campaign, Douglas notes, was 'the wronged husband, left with the millstone of the ex-wife around his neck'. ${ }^{69}$ The same picture is painted by media reports now, even though the facts in the cases being reported continue to tell a different story.

On closer analysis of the Mills $v$ Mills Court of Appeal judgment, ${ }^{70}$ a more balanced picture can be gleaned than the one portrayed in press reports. Ms Mills was awarded an increase in periodical payments to meet her needs, ${ }^{71}$ an increase which was subsequently

63 Gibb and Ames (n 59).

64 Churchill and Prynn (n 57).

65 There are other reports in tabloids such as The Sun (Laura Burnip, "IT'S GROSSLY UNFAIR" Ex-Husband Forced by Judge to "Support Ex-wife for Life" after She Blew $£^{230,000}$ Divorce Payout Slams "Unfair" System' The Sun (London, 8 February 2017) <www.thesun.co.uk/news/2816831/ex-husband-forced-tosupport-wife-for-live-slams-system/>) and the Daily Mirror (Ann Stenhouse, 'Divorcee Who Blew Settlement Money Wins Higher Maintenance from Ex - and He Must Support Her for LIFE' Daily Mirror <www.mirror.co.uk/news/uk-news/divorcee-who-blew-settlement-money-9769361>) which fit the sample frame and repeat many of the aspersions cast on Ms Mills but do not add anything new to the analysis in this section, other than to further illustrate how stereotypes about wives are communicated to readers in mainstream news outlets.

66 Miles and Hitchings (n 11).

67 Frances (n 3).

68 Gibb (n 21).

69 Douglas (n 5) 124.

70 For a more detailed account of this case, see Heenan ( $\mathrm{n} 45$ ).

71 In 2002, the parties' financial claims were settled on divorce by a consent order, providing Ms Mills with a capital sum and periodical payments of $£, 1100 \mathrm{pcm}$ for joint lives. The case currently before the court was brought by Mr Mills in 2014, who sought to discharge or reduce the periodical payments being made to Ms Mills. 
overturned by the Supreme Court in $2018 .{ }^{72}$ The Court of Appeal found that, although Ms Mills had made unwise investments, ${ }^{73}$ there had not been financial mismanagement, ${ }^{74}$ and the court was clear that Ms Mills had not been 'profligate or wanton'. ${ }^{75}$ There was nothing to suggest that Ms Mills was a gold-digger or alimony drone, nor did her unwise investments indicate mercenary intentions. Yet, in all six press reports assessed above, Ms Mills is either castigated for being a gold-digger, or (in the reports where she gives her own account) she is defending herself from the gold-digger accusation. This is because when the parties first separated a joint lives order was made (interpreted in the press as a meal ticket for life). This joint lives order was not affected by the Supreme Court's decision in this case; the court simply restored the level of maintenance to the level it had been before the Court of Appeal decision. ${ }^{76}$ The vilification of Ms Mills for receiving this award does not provide space for discussion of the potential utility of a joint lives order in some cases. It may well be an appropriate response to enduring economic disadvantage following relationship breakdown, especially given Miles and Hitchings' findings that:

... a clean break does not necessarily indicate that the economically weaker party can be fully self-supporting. She may only be able to avoid reliance on the exhusband by relying instead on others, or she may have no obvious adequate alternative means of support at all. ${ }^{77}$

However, the press's panic about meal tickets for life suggests that joint lives orders are never justified. On the rare occasion that a joint lives order is made (or, in the Mills case, is not discharged), the recipient (if a woman) will be labelled a gold-digger or alimony drone regardless of her intentions or whether the recipient fits the dictionary definition of these terms.

This is not to say there are not women who fit the dictionary definition of golddiggers and alimony drones, but equally, there might be men entering marriage with mercenary intentions too. However, these stereotypes, by their very definition, make us question women, not men. Irrespective of this, English law does not encourage golddigging, but it does have the capacity to recognise care. Both spouses, especially after long marriages, should be able to leave the marriage independently and on an equal footing economically. ${ }^{78}$ The court will not order a clean break if this will leave one party much worse off that the other. ${ }^{79}$ Yet the "clear "steer" in favour of the clean break' noted by Douglas ${ }^{80}$ indicates that, in recent case law, ${ }^{81}$ there is a firmly embedded expectation that wives will become self-sufficient following relationship breakdown.

The real gold-diggers, therefore, will be outwitted if they believe the myth that under English law the spouse will always get half of all assets on divorce or a meal ticket for life. If the court hears that the marriage has been short, and that little contribution has

72 Mills (n 17).

73 Mills (n 16) [12].

74 Ibid [13].

75 Ibid.

76 Mills (n 17).

77 Miles and Hitchings (n 11).

78 Miller v Miller; McFarlane v McFarlane [2006] UKHL 24.

79 A clean break is more difficult where there is less property and capital to divide up because there must be enough to meet the needs of the parties. See Emma Hitchings, 'The Impact of Recent Ancillary Relief Jurisprudence in the "Everyday" Ancillary Relief Case' (2010) 22(1) Child and Family Law Quarterly 93.

80 Douglas (n 5) 127.

81 Matthews v Matthews [2013] EWCA Civ 1874; SS v NS (Spousal Maintenance) [2014] EWHC 4183 (Fam); L v L (Financial Remedies: Deferred Clean Break) [2011] EWHC 2207 (Fam); Wright v Wright [2015] EWCA Civ 201. 
been made to the marriage, the non-moneyed spouse will not be entitled to a large award. ${ }^{82}$ Taking all of this into account, the media backlash indicated by press coverage of cases such as Mills $v$ Mills has helped perpetuate a moral panic about gold-diggers and alimony drones and has propagated myths about the law of financial provision on divorce. ${ }^{83}$ This is considered further in the following section, where the consequences of myths about financial provision on divorce are inspected more closely.

\section{Myths about financial provision on divorce}

The assertion in press reports on Mills $v$ Mills - that the law encourages gold-diggers and alimony drones - has encouraged a moral panic that financial provision in divorce is in urgent need of reform so that husbands can protect their property. Without any robust academic proof that there is an issue with gold-digging or alimony-droning wives, women are routinely castigated as such. Even worse, these charges obscure the research showing women in fact do worse than men on relationship breakdown across all levels of wealth. ${ }^{84}$ Stereotypes about wives cause a backlash against the equality so far achieved under law.

In the landmark case White $v W$ bite, Lord Nicholls said that, when it comes to dividing assets on divorce, non-financial contributions to the welfare of the family such as reproductive labour, domestic labour and care for dependants must be valued as much as economic contributions. ${ }^{85}$ Recognising the value of unpaid work in the home is important, Lord Nicholls said, because the division of labour in the marriage is gendered, and when someone's financial contributions are deemed more important by the law, the person responsible for contributing to the non-financial parts of family life is left at a disadvantage. 86

Unfortunately, in spite of such judicial attempts to say that care matters and should be valued economically, non-financial contributions are consistently devalued in society. ${ }^{87}$ Recent calls for divorce reform would undermine judicial efforts to raise consciousness about the more gendered aspects of both financial provision on divorce and prenuptial agreements. ${ }^{88}$ Importantly, these calls for reform are not only from Mr Mills and other disgruntled husbands who are given prominent voices in press reports. As this section will show, those in positions of authority are also advocating reform based on the flawed assertion that the law of financial provision on divorce encourages gold-diggers and

82 This was reinforced in Sharp v Sharp [2017] EWCA Civ 408.

83 Other financial provision cases where the wife has been portrayed as a gold-digger or alimony drone include Crossley v Crossley [2007] EWCA Civ 1491 (Amanda Cable, 'How I Saw off Serial Divorcée Susan Sangster, by Husband Number 4' Daily Mail (London, 25 February 2008) <www.dailymail.co.uk/femail/article517365/How-I-saw-serial-divorc-e-Susan-Sangster-husband-Number-4.html>); Miller v Miller [2006] UKHL 24 and Charman v Charman [2006] EWCA Civ 1791 (which were used as examples of a flawed system of financial provision on divorce by Ruth Deech: 'It's Time to Update our Divorce Laws' The Guardian (London, 15 September 2009) <www.theguardian.com/commentisfree/2009/sep/15/divorce-lawmaintenance-update $>$ ). Though Heather Mills has been cast as the archetypal gold-digger following McCartney v McCartney [2008] EWHC 401 (Fam), there is some evidence of stereotypes surrounding this case being challenged in the liberal press, though these reports are much less prevalent (see Kira Cochrane, 'Why We Love to Hate Heather' The Guardian (London, 20 March 2008) <www.theguardian.com/uk/2008/mar/20/mccartneydivorce.pressandpublishing>.

84 Hayley Fisher and Hamish Low, 'Recovery from Divorce: Comparing High and Low-income Couples' (2016) 30 International Journal of Law, Policy and the Family 338.

85 White (n 12).

86 Ibid [24].

87 See Heenan (n 45).

88 See Radmacher v Granatino [2010] UKSC 42, at [175]-[176] (Lady Hale). 
alimony drones, further embedding stereotypes about women and the myths these stereotypes promulgate.

If gold-digging is pathologised as a female trait, ${ }^{89}$ the ramifications for reform of financial provision can be concerning. This becomes clear when one places oneself in the position of someone who has only read press reports on Mr Mills' framing of the outcome of his case as unjust. This individual then goes on to read the views of Baroness Deech, who is one of the authorities on family law in the House of Lords and is one of the 'legal grandees' 90 supporting The Times' call for an end to meal-ticket-for-life awards. ${ }^{91}$ In press reports Baroness Deech directly refers to Mills v Mills. She believes the outcome was wrong in this case and the law needs to be reformed:

Our judges are being very old fashioned I'm afraid. They are over-chivalrous and the way they were in the 19th century. People wonder why, 15 years after a marriage has ended, one person has to keep paying money to another. ${ }^{92}$

Here, Baroness Deech is confirming suspicions about the judiciary after reading onesided accounts of Mr Mills' plight. Her words are persuasive in a society that vilifies golddiggers and celebrates (at least in this context) 'independent women':

If there is one thing that stops women getting back on their feet and being treated seriously and equally at work, it is the assumption throughout the legal system that once a woman is married she is somehow disabled and incapable ever of managing on her own for the rest of her life. It is a very serious impediment to equality. ${ }^{93}$

On this view, the law of financial provision on divorce is obstructing gender equality by sending a message that women are not as capable of independence as men are. Here, Baroness Deech's perspective is different from the press reports concerned with injustice to married men, but it is no less powerful. Baroness Deech's assertion is that the law is equally unjust to men and women because the law infantilises women, making it difficult for them to shake the 'housewife' image and be taken seriously as 'independent women'.

Baroness Deech's argument that the current law is anti-equality is ostensibly persuasive. She says that the disadvantages experienced by married women in the public sphere are not attributable to their husbands and that our law legitimises the attitudes of employers who discriminate against women because, in her view, they are aware that the law rewards gold-diggers and alimony drones. And so Baroness Deech has proposed reform which, she says, could help women to be more equal and independent in society. ${ }^{94}$

89 Press reports about gold-diggers and alimony drones are undoubtedly influential, but the power of these stereotypes is strengthened much more when those in positions of authority claim there is proof women do want rich men. One pertinent example of this in Canada is Justice Bauman's acceptance as evidence that women had evolved the tendency to be gold-diggers, based on the work of evolutionary psychologists: In Reference re: Section 293 of the Criminal Code of Canada, 2011 BCSC 1588, 555 (a case on the legality of polygamy).

90 Gibb (n 21).

91 Her views are supported by Baroness Fiona Shackleton, another lifelong peer and family law expert (see HL Deb 11 May 2018, vol 791).

92 Patrick Sawyer, 'Divorces are Skewed by Judges' Outdated Chivalry, says Female Peer Pushing for Cap on Payments' The Telegraph (London, 12 February 2017) <www.telegraph.co.uk/news/2017/02/12/divorcesskewed-judges-antiquated-chivalry-says-female-peer $/>$.

93 Ibid.

94 HL Deb 11 May 2018, vol 791, col 379. 
The Divorce (Financial Provision) Bill 2017-2019 aims to reform the law of financial provision on divorce by doing three things. ${ }^{95}$ First, it provides for an equal division of assets acquired during the marriage (but excluding assets acquired before the marriage, and property acquired through gift or inheritance). Secondly, the Bill seeks to curb periodical payments to no longer than five years (unless this would lead to 'serious financial hardship'). Finally, the Bill would make prenuptial and postnuptial agreements binding. ${ }^{96}$ The Bill includes standard procedural safeguards such as requirements of independent advice, cool-off periods and disclosure but, importantly, the Bill does not include any scope to set these agreements aside if their effect would be to leave one person in a position of need (which the court currently has discretion to do). ${ }^{97}$

The combined effect of these clauses is to reduce the discretion afforded to the judiciary to ensure substantive equality. ${ }^{98}$ As Baroness Deech's views are based on a liberal and formal version of equality, her Bill elides structural inequalities that discriminate against those made economically dependent through care. By citing independence, individual responsibility and choice as desirable conditions over and above those connected to the ethic of care, proposals are directed to the upper and middle classes and would detrimentally affect the non-moneyed spouse. Talk of gold-diggers, alimony drones and independent women therefore takes place in a context of what Tronto calls 'privileged irresponsibility'. ${ }^{99}$ Men and women who are in conditions of privileged irresponsibility can take on public duties and leave behind private duties. ${ }^{100}$ Even after separation, they can afford to pay someone else to clean their house and help care for their children. And so those who are not in such conditions of privileged irresponsibility stand to lose the most from the prevalence of stereotypes about wives and the myths about divorce such stereotypes promulgate, which fuel support for reform like that proposed by Baroness Deech.

\section{Countering myths in the courtroom and beyond}

So far, this article has argued that, in order to understand how stereotypes like 'golddigger' and 'alimony drone' impact on women, it is necessary to consider the discourses within which these stereotypes are situated. But it is also necessary to confront the potentially damaging effect of these stereotypes and the question of what can be done to counter them in practice.

Baroness Deech frequently refers to the gold-digger when advocating for the passage of her Private Member's Bill. Indeed, when she first introduced the Bill in 2014 she said it was necessary to fortify the system of financial provision on divorce against exploitation by the 'gold-digger' who has 'deprived irrationally [a man] of everything he had worked for' ${ }^{101}$

This quotation is powerful because it corroborates the stereotypes about wives in press reports and further entrenches myths about divorce because these words are spoken

95 At the time of writing, this Bill had progressed through the House of Lords and was awaiting its Second Reading in the House of Commons.

96 These agreements currently have decisive weight unless this would, in the prevailing circumstances, lead to unfairness: Radmacher (n 88).

97 For an overview of the status of prenuptial agreements in England and Wales, see Thompson (n 42) ch 1.

98 For a more detailed critique of this Bill, see Sharon Thompson and Russell Sandberg, 'Common Defects of the Divorce Bill and Arbitration and Mediation Services (Equality) Bill 2016-17' (2017) 47 Family Law 425.

99 Tronto (n 41) 60.

100 Ibid.

101 HL Deb 27 June 2014, vol 754, col 1491. 
in Parliament by a peer with expertise in family law. By stepping into the debate with concrete reform proposals, Baroness Deech has fuelled suspicions that the law is undeservedly generous to wives and has ostensibly provided a solution to this problem with her Bill. However, research has consistently contradicted Baroness Deech's view, proving that, instead of focusing on the mythical prevalence of meal tickets for life, a real matter of concern should be women's economically precarious position on divorce. ${ }^{102}$ Economic dependency within the family is based on gendered social values and is not simply encouraged by the system of financial provision in England and Wales, just as career sacrifices made by women are not, as Baroness Deech has said, simply a 'matter of choice'. ${ }^{103}$ Indeed, Baroness Deech's argument that such sacrifices are simply down to the choice of the individual is another hallmark of the 'privileged irresponsibility' within her brand of formal equality. The freedom of one's choices depends on the conditions an individual is in. ${ }^{104}$ Choice does not mean the same thing as equality, according to Tronto, because equal opportunity 'is a myth if there is no equality of care for children'. ${ }^{105}$ As a result, while research shows there are more female breadwinners than ever before, this should not lead to assumptions as to the modern division of labour in the home, especially when the marriage has produced children. ${ }^{106}$ As Cynthia Lee Starnes has put it:

According to myth, in today's egalitarian, gender-neutral culture mothers and fathers co-parent, both working full-time in the paid economy and sharing equally in their leisure time the few family tasks that are really necessary ... [yet] Even when a married mother works outside her home she likely serves as the primary caretaker, undertaking a disproportionately large share of household chores. ${ }^{107}$

Taking all of this into account, the assertions in Parliament ${ }^{108}$ that the law encourages gold-diggers and alimony drones is damaging. In the short term, it could lead to reform that would be disastrous for those primarily responsible for care in the marriage. In the longer term, as these assertions have gone unchallenged in the House of Lords since 2014 and are still consistently reported in the press, their legitimacy has increased. It is therefore important that the negative consequences of these stereotypes are properly factored into questions surrounding legislative reform of financial provision on divorce. At the very least, it is important that the myths about divorce created by these stereotypes are challenged directly in future parliamentary debates.

Unfortunately, stereotypes about wives and corresponding myths about divorce are not only a problem for debates around legislative reform. The impact on public perception of the law is also important since many people now determine the financial consequences of divorce for themselves, either by signing a nuptial agreement or by reaching a settlement on divorce.

102 See Heenan (n 45) 88.

103 Ruth Deech, 'What's a Woman Worth?’ (2009) 39(12) Family Law 1140.

104 Thompson (n 42) ch 6.

105 Tronto (n 41) 41.

106 Office for National Statistics, Families and the Labour Market, England: 2018, 3 October 2018 <www.ons.gov.uk/employmentandlabourmarket/peopleinwork/employmentandemployeetypes/articles/fam iliesandthelabourmarketengland/2018>.

107 Cynthia L Starnes, 'Mothers, Myths, and the Law of Divorce: One More Feminist Cast for Partnership' (2006) 13(1) William and Mary Journal of Women and Law203, 208.

108 Not just by Baroness Deech. For example, Lord Davies asserted '[p]eople have been deeply offended by some of the gold-digging - that is the word one must use - that has had a lot of publicity recently': HL Deb (2014) 754, cols 1496-1497. 
As I have argued previously, this was evident in my own empirical research. ${ }^{109}$ When researching prenuptial agreements, I interviewed attorneys in New York and found that often the non-moneyed spouse signs a prenup to prove she is not marrying for money, or the moneyed spouse insists on a prenup to be reassured he is not marrying a gold-digger. Women are more inclined to sign agreements out of fear of confirming the alimonydroning, gold-digging stereotypes. To use one example from my interviews, the attorney explained that he had a client that used these stereotypes to his advantage:

She did not want the prenup. [My client] insisted and at the last minute he capitulated and said it was alright. It was almost like it was a test. And because she said she would do it, [he knew] 'ok you're not marrying me for my money'.110

Why, as in this example, would a woman sign an agreement that she did not want to sign? One reason is that by not signing, women are faced with the threat of confirming stereotypes about wives. Focusing only on the motivations of the non-moneyed spouse not only leads to a false impression of the prevalence of gold-diggers and alimony drones, but also has a detrimental impact on financial outcomes on divorce. Parties may not ask for more money out of a fear of confirming such stereotypes. And so moral panics about gold-diggers and alimony drones add an extra layer of coercion to financial settlements and nuptial agreements. The recent English High Court case $K A v M A^{111}$ provides an example of the effect such stereotypes can have. In this case, the wife was 'psychologically torn' between proceeding with the wedding and signing an agreement 'which might well, at some point in the future, operate to her significant financial detriment'. 112 Roberts J considered the wife's reasons for entering the prenup, finding that the wife 'took this course for what may have been the best of reasons . . . motivated principally by what she perceived to be in their son's best interests'. ${ }^{113}$ She even suspected that the wife did not make much attempt to ask for more under the agreement ${ }^{114}$ out of fear that the wedding would not go ahead. ${ }^{115}$ 'I am not like that', ${ }^{116}$ the wife said. Taking the circumstances of this case into account, it was clear what she meant by 'that'. By refusing to ask for more money under the terms of the prenup, she would show she was not a gold-digger or a future alimony drone. She would not be labelled the 'cold, cunning chancer', 117 as Ms Mills had been in the Mail on Sunday. And her wedding could go ahead.

These examples indicate that tropes like 'alimony drone', 'gold-digger' and 'meal ticket for life' are influencing individuals' decision-making. When media narratives place emphasis on these tropes, the intentions of the non-moneyed (not the moneyed) party are interrogated in a way that does not place the non-moneyed parties' financial demands, needs and choices on a par with those of the moneyed spouse. In practice this can lead to spouses agreeing to financial settlements that will ultimately affect them detrimentally. Furthermore, focusing on whether someone is a gold-digger, or on requiring her to prove to the world that she will never be economically dependent (and signing entitlement away accordingly), facilitates a shift in emphasis away from valuing care and other non-financial contributions. The impact of devaluing care on relationship breakdown is that structural

109 Thompson (n 42) ch 3.

110 Ibid 196.

111 KA v MA (Prenuptial Agreement: Needs) [2018] EWHC 499 (Fam).

112 Ibid [63].

113 Ibid [65].

114 The husband increased his proposal once after the wife suggested it was 'a bit mean': ibid [63].

115 Ibid.

116 Ibid (emphasis added).

117 Craig (n 60). 
inequalities are reinforced and those who do make the non-financial contributions to the welfare of the family are disadvantaged.

Research shows how gendered this work still is. In November 2016, the Office for National Statistics reported that women across all wealth brackets take longer to recover after divorce than men. ${ }^{118}$ The work of Fisher and Low also indicates that women take longer to recover economically on relationship breakdown at all levels of wealth. ${ }^{119}$ And so limiting financial provision to care-giving spouses is neither a safe nor productive strategy for addressing structural inequalities between men and women. But the mealticket, gold-digger mentality does not appreciate this reality.

However, confronting the question of what can be done to counter these tropes is difficult. Explaining the law on financial provision to those who are certain it makes women treat men like cash machines ${ }^{120}$ feels impossible in the current climate. Not only is the law in this area complex; the press reports assessed above indicate that the voices of experts are being drowned out by more forceful voices shouting about injustice when they see women receive substantial awards on divorce. There is a perception that capital earned by the moneyed spouse is his alone, rather than capital generated directly and indirectly by both spouses working outside and inside the home. This is connected to the view that women who are awarded a share in this capital on divorce must be gold-diggers or alimony drones.

In spite of these difficulties, it is important that something is done. The influence stereotypes about wives have must be acknowledged and condemned in the courtroom. In Waggott $v$ Waggott, ${ }^{121}$ the wife's counsel raised this very issue, and according to Moylan LJ, he was:
. . e evidently concerned that recent public debate about how the courts determine a spouse's claim for maintenance might somehow intrude into the determination of this case. His particular focus was what he described as the unfair use of the expression 'meal ticket for life' which, he suggested, was often deployed without regard to a spouse's fair entitlement which might properly include long-term maintenance. ${ }^{122}$

Ms Waggott's counsel was concerned that his client would be portrayed as an alimony drone or gold-digger for seeking an award that would place her on equal financial footing with her husband on divorce. ${ }^{123}$ In response, Moylan LJ noted that he understood the expression 'meal ticket for life' 'can be used as an unfair trope' but refused to comment further. While it is commended that Moylan LJ recognised the unfairness of this stereotype, his judgment in Waggott could have engaged further with the influence of stereotypes in financial provision cases. Similarly, in his leading judgment in the Supreme Court in Mills, Lord Wilson said it was 'misleading' and 'unattractive' for joint lives orders to be described as being meal tickets for life but did not assess the impact of this phrase further. ${ }^{124}$

118 Office for National Statistics, Women Shoulder the Responsibility of 'Unpaid Work' (10 November 2016) <www.ons.gov.uk/employmentandlabourmarket/peopleinwork/earningsandworkinghours/articles/womens houldertheresponsibilityofunpaidwork/2016-11-10>.

119 Fisher and Low (n 84).

120 Daubney (n 55).

121 Waggott $v$ Waggott [2018] EWCA Civ 727.

122 Ibid [156].

123 She had left employment in 2001 and (apart from a short period in 2002/2003) had not worked in paid employment since, while the husband's career went from strength to strength: ibid [17].

124 Mills (n 17) [25]. 
Reflexive engagement with stereotypes should be an important part of judicial reasoning. There is a gap between what the law is and what social perceptions of the law are, and accurate information on the law ${ }^{125}$ and evidence of the detrimental impact of tropes like alimony drone, gold-digger and meal ticket for life are important. Much has been written about the conditions that lead to power inequalities in intimate financial agreements, and conditions that lead to inequality of bargaining power are crucial to understanding how people make decisions in relationships. ${ }^{126}$ But individuals' social perceptions are important too. Judgment-making has the potential to be an important influence in practice.

Judicial opinion will not counteract media stereotypes by ignoring them, and so there must be direct engagement with the negative consequences of such stereotypes on women. Failing to do so arguably obstructs justice which, as Tronto notes, 'requires honest exploration of the social, economic and political institutions that constrain people's lives'. ${ }^{127}$ The influence of the moral panic surrounding stereotypes about wives is part of this context, as it directs attention towards the perception that overly generous awards are made and away from the detrimental impact of divorce on women. ${ }^{128}$ This not only mis-frames important concerns, it also potentially reinforces the prevalence of cleanbreak orders in practice, which in turn affects the economic recovery of women after divorce. Unfounded stereotypes should not be relied upon at the expense of those in need of provision. By reflexively engaging with misplaced concerns in the courtroom, there is greater scope for members of the judiciary to interrogate parties' capacity for economic self-sufficiency instead of assuming that this will be possible following separation.

One way of doing this could be to bring 'social reality to the courtroom'129 by taking 'judicial notice' of the gendered impact that stereotypes about wives can have. This would mean that the impact of derogatory, women-centred terms like 'gold-digger' and 'alimony drone' would be explicitly acknowledged, so that a factual inquiry into parties' actual (not assumed) ${ }^{130}$ capacities to become self-sufficient can be scrutinised. Therefore, when considering whether to make a clean-break order, the court would invariably pay attention to evidence-based research of women's experiences and of empirical research on the financial impact of divorce and its impoverishing effect on women and children, instead of moral panics that have been shown to be ill-founded. ${ }^{131}$ The doctrine of judicial notice, whereby a judge 'assume[s] a position of authority to find a "social fact" that

125 See, for example, the work of The Transparency Project at <www.transparencyproject.org.uk/>.

126 Alison Diduck, 'Autonomy and Family Justice' (2016) 28 Child and Family Law Quarterly 133; Anne Barlow and Janet Smithson, 'Is Modern Marriage a Bargain? Exploring Perceptions of Pre-nuptial Agreements in England and Wales' (2012) 24 Child and Family Law Quarterly 304.

127 Tronto (n 41) 41.

128 Miles and Hitchings (n 11).

129 Claire L Heureux-Dubé, 'Re-examining the Doctrine of Judicial Notice in the Family Law Context' (1994) 26 Ottowa Law Review 551, 551.

130 Miles and Hitchings' study found that a clean break is frequently ordered without clear absence of the parties' abilities to become self-sufficient (n 11).

131 This is an area where there is a clear contrast in family law between money and children cases due to the case management process. In children cases, the Children and Family Court Advisory and Support Service will bring in some relevant empirical evidence on child development to an individual case. See Bryan Rodgers, Liz Trinder and Teresa Williams, Towards a Family Justice Observatory to Improve the Generation and Application of Research (Nuffield Foundation 2015). 
requires no reference,' 132 is controversial (particularly in US jurisprudence) ${ }^{133}$ in that it is an exercise of power because it depends upon his or her extra-legal, 'social' knowledge. 134 Acknowledging these difficulties, however, Claire Heureux-Dubé argues that the family law context is particularly well-suited to the use of judicial notice, as it enables the judiciary to assess 'the true consequences from the relationship and its breakup ... formulating a more accurate picture of the realistic needs of the parties, particularly when self-sufficiency ... [is] at issue'. ${ }^{135}$ Using judicial notice in this way allows the judge to challenge stereotypes and to better understand the context in which financial matters are negotiated between parties on divorce. A possible counter-argument to this is that explicitly referencing stereotypes in judgment-writing could lead to accusations of bias in favour of wives. Claims of neutrality and objectivity in judicial reasoning are often criticised in feminist scholarship, ${ }^{136}$ for members of the judiciary are inevitably influenced by their own experiences and opinions. Yet failing to directly acknowledge such stereotypes is arguably neither neutral nor objective either, when there is evidence they are detrimentally affecting women on divorce.

Appropriating the tools of feminist judgment-writing could assist in this regard. ${ }^{137}$ One notable aspect of feminist judgment-writing is the central influence of care, emphasising the importance of relationships and interconnectedness instead of autonomy and independence. ${ }^{138}$ This shift in emphasis is important given the neoliberal mantra that 'autonomy is good for you', which has repeatedly been used to legitimise the relegation of family disputes to the private sphere. The zenith of this change has been the virtual obliteration of legal aid in family law cases since 2012, a reform which Jess Mant argues is rooted in neoliberal ideology in that individuals are supposed to have responsibility for their own circumstances, whatever the structural barriers they experience. ${ }^{139}$ The narrative of self-sufficiency in tandem with the backlash against dependency created by media stereotypes and Baroness Deech's proposed reform has created a hostile environment for the recognition and valuation of care. But by employing the tools of feminist judgment-writing, the courtroom can become a 'site of resistance to persistent gendered norms'140 and stereotypes affecting the negotiation of financial settlements and nuptial agreements. Furthermore, as Judith Masson ${ }^{141}$ and Duncan Kennedy ${ }^{142}$ have argued, judgment-making is deliberative and strategic. Judges can shape 'not just an individual decision but the law itself through the focus and construction of

132 Heather Douglas, Francesca Bartlett, Trish Luker and Rosemary Hunter, 'Reflections on Rewriting the Law' in Heather Douglas, Francesca Bartlett, Trish Luker and Rosemary Hunter (eds), Australian Feminist Judgments: Righting and Rewriting Law (Hart 2014) 26.

133 Heureux-Dubé (n 129) 553.

134 Douglas et al (n 132) 26.

135 Heureux-Dubé (n 129) 576.

136 Douglas et al (n 132) 24.

137 Rosemary Hunter, Clare McGlynn and Erika Rackley (eds), Feminist Judgments (Hart 2010).

138 Douglas et al (n 132) 27. I also argue that this approach could be important for contract law in Sharon Thompson, 'Feminist Relational Contract Theory: A New Model for Family Property Agreements' (2018) 45(4) Journal of Law and Society 617.

139 Jess Mant, 'Neoliberalism, Family Law and the Cost of Access to Justice' (2017) 39(2) Journal of Social Welfare and Family Law 246.

140 Douglas et al (n 132) 26.

141 Judith Masson, 'Disruptive Judgments' (2017) 29(4) Child and Family Law Quarterly 401.

142 Duncan Kennedy, 'Freedom and Constraint in Adjudication' (1986) 36 Journal of Legal Education 518. 
their judgments, even when another outcome of the case appears certain', and the content of judgments may be used for deliberate effect. ${ }^{143}$

\section{Conclusion}

Baroness Deech has consistently emphasised the need for reform of financial provision on divorce because of the perception that current law infantilises women. 'Younger academics . . . are reinventing the wheel', she says, by portraying women as victims. ${ }^{144}$ Respectfully, I disagree. Concern for those with caring commitments in marriage is not based on antiquated ideas as suggested by Baroness Deech; it is a live issue. In the last decade, neoliberal policies have systematically devalued care and privileged those who do not care. ${ }^{145}$ While the traditional dichotomy of housewife and breadwinner may no longer be as representative, normative expectations of care have instead resulted in women performing dual roles of both paid (often part-time) work and unpaid caregiving. ${ }^{146}$ Recognising this and listening to the voices of the women (and men) who want their non-financial contributions to be valued is not to treat caregivers as victims; it is to recognise that a focus on maximising and protecting personal wealth ignores the realities of economic dependency in family life. However, this is not the story told in press reports. Instead, as this article has shown, wives are portrayed as alimony drones and gold-diggers who are parasitic on wealthy men. The phrase 'meal ticket for life' is employed repeatedly in these reports too, even though research has proven quantitatively and empirically that lifetime maintenance is not only rare, ${ }^{147}$ but that women across all levels of wealth are economically worse off on divorce than men. ${ }^{148}$ The research also suggests that proliferation of such stereotypes has created barriers for women when negotiating financial settlements and nuptial agreements, widening the gender gap on divorce even more.

Stereotypes about wives contribute to misunderstandings as to how the 'everyday' divorce $^{149}$ affects the spouse who has undertaken most of the non-financial work in the relationship, who is still usually the wife. And when the language of 'gold-digger', 'alimony drone' or 'meal-ticket for life' enters the debate, women must work much harder to justify getting what they are legitimately entitled to on divorce. Moreover, these stereotypes contribute to the drowning out of other concerns, such as Lord Nicholls' compelling call for equality after divorce in 2000: 'whatever the division of labour chosen by the husband and wife, or forced upon them by circumstances, fairness requires that this should not prejudice or advantage either party'. ${ }^{150}$ Unfortunately, this judicial support for equality has not addressed the ongoing unequal economic impact of divorce on men and women. 151

143 Masson (n 141) 404.

144 HL Deb 11 May 2018, vol 791, col 402.

145 See Anne Barlow, Jan Ewing, Janet Smithson, and Rosemary Hunter, Mapping Paths to Family Justice: Resolving Family Disputes in Neoliberal Times (Palgrave 2017).

146 Anne Barlow, 'Configurations of Unpaid Caregiving within Current Legal Discourse in and around the Family’ (2007) 58(3) Northern Ireland Legal Quarterly 251, 252.

147 Miles and Hitchings (n 11).

148 Fisher and Low (n 84).

149 Hitchings (n 79).

150 White (n 12) [24].

151 In fact, as Miles and Hitchings' interview findings show, it is the norm of the clean break, not the meal ticket that prevails in legal practice, and this has 'produced outcomes that [appear] to have left some wives badly under-protected': Miles and Hitchings (n 11). 
When inequality is bound up in complex political, social, economic and historical structures, there is no clear solution to closing the gap between men and women on divorce. However, negative stereotypes about wives are exacerbating these inequalities, creating false problems and simplistic solutions. As this article has argued, the court has a role to play in tackling the barriers created by such stereotypes. The case study of Mills $v$ Mills is a clear demonstration of how myths about gold-diggers and alimony drones are propagated. Perhaps most worryingly, these press reports contribute to the misinformed perception that the law encourages and indulges the behaviour of money-grabbing wives. More broadly, judicial reasoning in financial provision cases should no longer ignore the impact that stereotypes about wives can have. Simply acknowledging these stereotypes is not enough; as this article has argued, judicial reasoning should go further and reflexively engage with the practical impact such stereotypes can have. ${ }^{152}$ For, when these stereotypes are not addressed in the courtroom or challenged in Parliament, their harm is indirectly legitimised.

$152 \mathrm{By}$, for example, taking judicial notice of empirical research on the financial impact on divorce, as discussed in this article. 
